\title{
PEMILIHAN GUBERNUR TAK LANGSUNG SEBAGAI PENEGASAN EKSISTENSI GUBERNUR SEBAGAI WAKIL PEMERINTAH PUSAT DI DAERAH
}

(Indirect Election of Governors as Confirmation of the Existence of Governors as the Representative of the Central Government in the Region)

\author{
Eko Noer Kristiyanto \\ Badan Pembinaan Hukum Nasional-Kementerian Hukum dan HAM RI \\ Jalan Mayjen Sutoyo Nomor 10 Jakarta Timur \\ E-mail: tigers_nova@yahoo.com
}

Naskah diterima: 10 Desember 2012; revisi: 15 Desember 2012; disetujui: 18 Desember 2012

\begin{abstract}
Abstrak
Dalam penyelenggaraan pemerintahan daerah, Dekonsentrasi dan tugas pembantuan diselenggarakan karena tidak semua wewenang dan tugas pemerintahan dapat dilakukan dengan menggunakan asas desentralisasi. Kedudukan provinsi menjadi unik karena melaksanakan desentralisasi dan dekonsentrasi secara bersamaan. Hal ini berimbas kepada kedudukan gubernur yang menyandang dua status yaitu sebagai kepala daerah sekaligus wakil pemerintah pusat di daerah. Peran yang perlu dioptimalkan agar penyelenggaraan negara berjalan baik adalah gubernur sebagai wakil pemerintah di daerah karena berkaitan dengan fungsi pembinaan, koordinasi dan pengawasan. Sistem pemilihan gubernur secara langsung ternyata justru berimplikasi bahwa gubernur lebih dominan perannya sebagai kepala daerah. Tulisan ini menjelaskan seperti apa kedudukan gubernur sesungguhnya dan menawarkan solusi seperti apa mekanisme pemilihan gubernur yang dianggap tepat. Terlepas dari segala kritiknya, pemilihan gubernur harus dilakukan secara tidak langsung, mengingat terbatasnya wewenang gubernur serta kedudukan dan tanggung jawab gubernur yang mendapat pelimpahan kewenangan dari pusat serta mengemban mandat dari presiden. Pemilihan oleh DPRD dianggap paling sesuai karena memenuhi unsur pemilihan secara demokratis yang diamanatkan oleh konstitusi.
\end{abstract}

Kata Kunci: Gubernur, Pemerintahan Daerah, Dekonsentrasi, Desentralisasi, Provinsi

\begin{abstract}
In the Regional Government deconcentration and assistance tasks organized because not all of the powers and duties of government can be done by using the principle of decentralization, the province is unique because decentralization and deconcentration simultaneously. This impact to the position of governor of the state that holds the two regions as well as head of government representatives of the central government in the region. The roles that need to be optimized so as the governor of the state is running well as representatives of governments in the region as it relates to the functions of guidance, coordination and supervision. System of direct election of governors proved to be implying that the governor is more dominant role as head of the region. This article explains what the real position of the governor and offer solutions as to what mechanism gubernatorial deemed appropriate. Despite all the criticism, the gubernatorial election must be done indirectly, given the limited authority of the governor and the status and responsibilities of governors who received the delegation of authority from the center as well as carry out the mandate of the president. The selection by the legislature considered the most appropriate because it meets substance democratic elections mandated by the constitution.

Keywords: Governors, Local Government, deconcentration, decentralization, Province
\end{abstract}




\section{A. Pendahuluan}

Negara Kesatuan Republik Indonesia dalam penyelenggaraan pemerintahannya menganut asas desentralisasi, dekonsentrasi, dan tugas pembantuan. Dekonsentrasi dan tugas pembantuan diselenggarakan karena tidak semua wewenang dan tugas pemerintahan dapat dilakukan dengan menggunakan asas desentralisasi. ${ }^{1}$ Desentralisasi adalah penyerahan kewenangan dari pemerintah pusat kepada pemerintah daerah untuk mengurusi urusan rumah tangganya sendiri berdasarkan prakarsa dan aspirasi dari rakyatnya dalam kerangka negara kesatuan Republik Indonesia. Dengan adanya desentralisasi maka muncul otonomi bagi suatu pemerintahan daerah. Desentralisasi sebenarnya adalah istilah dalam keorganisasian yang secara sederhana didefinisikan sebagai penyerahan kewenangan, sedangkan dekonsentrasi adalah pelimpahan wewenang dari pemerintah pusat kepada gubenur sebagai wakil pemerintah di wilayah provinsi.

Dalam sistem ketatanegaraan Indonesia, posisi gubernur menjadi unik dan khas, karena otonomi daerah dan pemilihan langsung di daerah telah menjadikan gubernur sebagai seorang kepala daerah, namun di sisi lain dengan adanya asas dekonsentrasi, maka gubernur pun bertindak sebagai wakil pemerintah pusat di daerah. Gubernur sebagai kepala daerah provinsi berfungsi pula sebagai wakil pemerintah pusat di daerah, dalam pengertian untuk menjembatani dan memperpendek rentang kendali pelaksanaan tugas dan fungsi pemerintahan, termasuk dalam pembinaan dan pengawasan terhadap penyelenggaraan urusan pemerintahan di kabupaten dan kota. ${ }^{2}$ Pengisian jabatan gubernur adalah sama dengan pengisian jabatan kepala daerah di kabupaten/kota, yaitu dipilih langsung oleh rakyat. Konstitusi memberi dasar bahwa pemilihan umum kepala daerah diselenggarakan secara demokratis, ${ }^{3}$ dan cara demokratis ini diimplementasikan dalam mekanisme pemilihan secara langsung oleh rakyat. ${ }^{4}$

Pemilihangubernur secara langsung ternyata menimbulkan persoalan, karena dengan dipilih secara langsung maka gubernur seringkali lebih menonjolkan sisi sebagai kepala daerah, hal ini dilatarbelakangikarena gubernur terpilih merasa mendapat legitimasi rakyat dan juga memiliki program-program yang pernah dijanjikan saat kampanye, kepercayaan diri gubernur terpilih cenderung tinggi dan seringkali melakukan kebijakan diluarwewenangnya, terlebih peranan sebagai wakil pemerintah pusat di daerah pun menjadi terabaikan, minimnya koordinasi di daerah, serta ketidakselarasan program pusat dan daerah yang berimplikasi terhadap buruknya pembangunan dan pelayanan publik di daerah. Berbagai kritik yang muncul menguatkan wacana bahwa sebaiknya pemilihan gubernur tidak perlu dilakukan secara langsung, bahkan payung hukum pun telah dipersiapkan untuk mekanisme pemilihan gubernur secara tidak langsung dimasa yang akan datang. ${ }^{5}$

Penjelasan Umum Peraturan Pemerintah Nomor 7 Tahun 2008 tentang Dekonsentrasi dan Tugas Pembantuan.

Suryo Sakti Hadiwijoyo, Gubernur, (Jakarta: Grha Ilmu, 2011), hlm.64

Pasal 18 ayat 4 Undang-Undang Dasar 1945.

Pasal 24 ayat 5 Undang-Undang Nomor 32 Tahun 2004 tentang Pemerintahan Daerah.

Menteri Dalam Negeri, Gamawan Fauzi mengatakan bahwa pemerintah mengusulkan bahwa dimasa yang akan datang pemilihan gubernur tidak perlu dilakukan secara langsung, hal ini termuat dalam revisi Undang-Undang Nomor 32 Tahun 2004 Tentang Pemerintahan Daerah. 


\section{B. Permasalahan}

1. Bagaimana kedudukan gubernur dalam sistem ketatanegaraan Indonesia?

2. Mengapa melakukan pemilihan gubernur secara tidak langsung menjadi alternatif yang baik dimasa yang akan datang?

\section{Metode Penelitian}

Metode penelitian yang digunakan dalam penulisan ini adalah metode penelitian hukum normatif. Metode penelitian hukum normatif pada dasarnya meneliti kaidah-kaidah hukum dan asas-asas hukum, ${ }^{6}$ menelaah permasalahan dengan berpedoman pada data sekunder yaitu: bahan hukum primer, sekunder dan tersier. Bahan hukum primer yang dimaksud adalah Undang-Undang Dasar 1945, undangundang, peraturan pemerintah, dan peraturan perundang-undangan lain yang berkaitan dengan judul penelitian.

Bahan hukum sekunder yang dimaksud adalah doktrin, ajaran para ahli, hasil karyailmiah para ahli, berita-berita dan hasil wawancara pihak terkait yang diperoleh dari surat kabar serta situs-situs internet yang relevan dengan judul penelitian.

Data di atas dikumpulkan melalui studi kepustakaan (library research), penelurusan melalui media internet (online research), dalam hal ini penulis menitikberatkan dalam konteks pemerintahan daerah, termasuk di dalamnya mengkaji seperti apa sesungguhnya kedudukan dan kewenangan gubernur dalam sistem ketatanegaraan Indonesia, lalu apakah peranan dominan sebagai kepala daerah yang dipilih langsung oleh rakyat membuat tugas dan kedudukan gubernur sebagai wakil pemerintah pusat di daerah menjadi bias bahkan tidak berjalan efektif sehingga menghambat program pemerintah pusat. Kemudian penulis akan mencoba menawarkan solusi dalam pemilihan gubernur sesuai dengan kedudukannya dalam sistem ketatanegaraan Indonesia.

\section{Pembahasan}

\section{Dekonsentrasi dan Kewenangan Gubernur}

Pelimpahan kewenangan pemerintahan pusat kepada gubernur adalah bentuk nyata dari pelaksanaan asas dekonsentrasi di Indonesia. ${ }^{7}$ Dekonsentrasi diberlakukan karena tidak semua wewenang dan tugas pemerintahan dapat dilaksanakan dengan menggunakan asas desentralisasi. Selain itu, sebagai negara kesatuan memang tak mungkin seluruh wewenang dan urusan pemerintah didesentralisasikan kepada daerah. ${ }^{8}$

Dekonsentrasi adalah pelimpahan wewenang administrasi dari pemerintah pusat kepada pejabatnya di daerah atau pejabatnya di wilayah

6 Bagir Manan, "Penelitian Terapan di Bidang Hukum", (makalah disampaikan pada Lokakarya Peranan Naskah Akademis Dalam Penyusunan Peraturan Perundang-undangan, BPHN, Jakarta, 9 - 11 November 1993), hlm. 7, lihat juga Soerjono Soekanto dan Sri Mamudji menyatakan bahwa penelitian hukum normatif atau penelitian hukum kepustakaan merupakan penelitian hukum yang dilakukan dengan cara meneliti bahan pustaka atau data sekunder belaka yaitu dengan cara menelaah permasalahan dengan berpedoman pada data sekunder.

7 Menurut Undang-Undang Nomor 32 Tahun 2004 Tentang Pemerintahan Daerah, asas dekonsentrasi diselenggarakan melalui dua cara, yaitu: pertama, pelimpahan kewenangan pemerintah kepada perangkat pusat di daerah; kedua, pelimpahan kewenangan pemerintah kepada gubernur sebagai wakil pemerintah di daerah.

8 Kewenangan daerah mencakup kewenangan dalam seluruh bidang pemerintahan, kecuali kewenangan dalam bidang politik luar negeri, pertahanan, keamanan, peradilan, moneter, fiskal, dan agama. 
negara di luar kantor pusatnya. ${ }^{9}$ Sehingga dalam konteks ini maka yang dilimpahkan adalah wewenang administrasinya, bukan wewenang politik. ${ }^{10}$ Gubernur adalah penerima wewenang dari pemerintah pusat, ${ }^{11}$ maka pada hakikatnya gubernur adalah pejabat pemerintah pusat namun ditempatkan di daerah, dalam hal ini sesungguhnya gubernur adalah bagian dari wilayah administratif yang merupakan bagian dari pusat, tugasnya pun sangat terbatas karena sebagai pelaksana administratif maka gubernur hanya menjadi pelaksana dari keputusan dan kebijakan pusat, secara hierarki administrasi pun sangat tegas bahwa gubernur menginduk kepada pemerintah pusat. ${ }^{12}$ Gubernur memiliki kedudukan sebagai wakil pemerintah pusat juga dikarenakan jabatannya, dan karena jabatan serta kedudukannya tersebut maka gubernur pun bertanggung jawab kepada presiden. ${ }^{13}$

Salah satu tujuan administratif dari kebijakan dekonsentrasi adalah pejabat dekonsentrasi dapat mengetahui apa yang menjadi potensi dan kebutuhan daerah, hal ini berkaitan dengan penyusunan program-program pusat ataupun daerah yang saling sinergis dan menunjang satu sama lain. ${ }^{14}$ Kehadiran dekonsentrasi, adalah semata-mata untuk melancarkan pemerintahan sentral/pusat di daerah. ${ }^{15}$ Dari uraian tersebut dapat terlihat bahwa gubernur sebagai pejabat dekonsentrasi seharusnya hanya berperan perantara antara pemerintah pusat dan daerah, sebatas administratif tanpa ada kewenangankewenangan politis. Dalam konteks ini sebenarnya peraturan perundang-undangan terkait pemerintahan daerah telah mengatur secara tegas mengenai kewenangan gubernur dan tidak memberi peluang untuk melebihi kewenangan administratif. Namun peran dan fungsi sebagai ujung tombak pemerintah pusat di daerah menjadi tak dapat terlaksana optimal jika gubernur dipilih secara langsung oleh rakyat, Hikmahanto Juwono mengatakan bahwa kerap terjadi kondisi dimana kepala daerah lebih mengutamakan kepentingan rakyat pemilihnya daripada kepentingan pemerintah pusat, karena yang ditafsirkan adalah amanah, mandat rakyat serta janji kampanye yang dalam banyak hal bisa jadi berbeda dengan garis kebijakan pemerintah pusat dalam tataran yang paling konkret. ${ }^{16}$

\section{Penguatan Peran Gubernur Sebagai Wakil Pemerintah Pusat di Daerah}

Sebenarnya pemerintah pun menyadari dan bersepakat bahwa dengan adanya asas dekonsentrasi dalam pemerintahan daerah maka gubernur haruslah lebih kuat peranannya sebagai wakil dari pemerintah pusat di daerah, ini terkait fungsi dan tugasnya sebagai pengawas, koordinator dan pembina kabupaten/kota. Dalam konteks itulah maka berbagai upaya

Hanif Nurcholis, Teori dan Praktek Pemerintahan dan Otonomi Daerah, (Jakarta:Grasindo, 2007), hlm. 18.

Ibid.

11 Pasal 1 butir 8 Undang-Undang Nomor 32 Tahun 2004 Tentang Pemerintahan Daerah menyatakan: "dekonsentrasi adalah pelimpahan wewenang dari pemerintah pusat kepada gubenur sebagai wakil pemerintah di wilayah provinsi."

12 Hal ini berbeda dengan konsep desentralisasi yang menciptakan otonomi dan daerah otonom seperti kabupaten/ kota.

13 Pasal 38 Undang-Undang Nomor 32 Tahun 2004 Tentang Pemerintahan Daerah.

14 Suryo Sakti Hadiwijoyo, Op.Cit., hlm. 67-68.

15 Bagir Manan dan Kuntana Magnar, Beberapa Masalah Hukum Tata Negara Indonesia (Bandung: Alumni, 1997), hlm. 274-275.

16 Inna Junaenah, "Implikasi Pemilihan Gubernur Secara Langsung Terhadap Kedudukan Gubernur Sebagai Wakil Pemerintah Pusat", Jurnal Konstitusi (Vol II Juni 2010): 61. 


\section{$\mathrm{R}_{\text {juknaL }}^{\text {juTSVINDING }}$}

Media Pembinaan Hukum Nasional

pun dilakukan untuk memperkuat kedudukan dan kewenangan gubernur sebagai wakil pemerintah pusat di daerah, salah satunya adalah diterbitkannya Undang-Undang Nomor 32 Tahun 2004 tentang Pemerintahan Daerah sebagai perubahan Undang-Undang Nomor 22 Tahun 1999. Dalam Undang-Undang Nomor 22 Tahun 1999 terdapat muatan yang membuat koordinasi pusat dan daerah menjadi bias bahkan yaitu pernyataan bahwa provinsi bukan merupakan pemerintah atasan dari kabupaten/ kota, dan hubungan antara provinsi dengan kabupaten/kota bukan merupakan hubungan hierarkis. ${ }^{17}$ Hal ini menimbulkan euforia kewenangan pada pemerintahan kabupaten/ kota, sehingga seringkali mengabaikan dan mengenyampingkan eksistensi provinsi maupun gubernur sebagai wakil pemerintah pusat di daerah. Hal seperti ini menyebabkan dampak negatif dalam proses penyelenggaraan pemerintahan daerah sebagai sub pemerintahan negara, daerah bergerak tanpa ada koordinasi dengan pusat, beberapa contoh adalah sebagai berikut: ${ }^{18}$

a. Para Bupati/Walikota di Riau dianggap membangkang terhadap Gubernur. Keberanian Bupati Kepulauan Riau (Kepri) Huzrin Hood dalam memperjuangkan Kepulauan Riau menjadi Provinsi tanpa adanya rekomendasi dari Gubernur Riau. MerekamemperjuangkanProvinsiKepulauan
Riau melalui DPR RI dan Pemerintah Pusat dengan melangkahi Gubernur Riau.

b. Para Bupati yang tidak pernah menghadiri rapat jika diundang oleh gubernur. ${ }^{19}$

c. Para Walikota dan Bupati yang cenderung membangkang terhadap Gubernur. ${ }^{20}$

Padahal penyelenggaraan urusan pemerintahan merupakan pelaksanaan hubungan kewenangan yang bersifat saling terkait, tergantung, dan sinergis antara pemerintah pusat dan pemerintah daerah atau antar pemerintahan daerah sebagai satu sistem pemerintahan. ${ }^{21}$

Ditiadakannya pernyataan tidak adanya hubungan hierarkis antara provinsi dengan kabupaten/kota dalam Undang-Undang Nomor 32 Tahun 2004 secara tidak langsung mengisyaratkan bahwa sesungguhnya hubungan hierarkis itu ada. Struktur hubungan kekuasaan antara pemerintahan pusat dengan provinsi dan kabupaten/kota ini bersifat pembagian yang bertingkat-tingkat, sehingga hal tersebut harus dilihat sebagai hubungan yang bersifat hierarkis. ${ }^{22}$ Perumusan Undang-Undang Nomor 22 Tahun 1999 yang menentukan bahwa pola hubungan antara provinsi dan kabupaten/ kota adalah bersifat horisontal menimbulkan kritik-kritik, karena sebagai akibat penerapan pengertian pola hubungan yang horisontal itu, timbul begitu banyak efek samping di daerahdaerah. ${ }^{23}$

17 Penjelasan Umum butir f Undang-Undang Nomor 22 T ahun 1999.

18 Kisno Hadi, "Satu Dasawarsa Relasi Politik Lokal Dan Nasional Dalam Konteks Otonomi Daerah" POLITIKA (vol 1 No 2 2010): 5.

19 Pernyataan Gubernur Jawa Tengah Bibit Waluyo pada 2009.

20 Pernyataan Gubernur Sulawesi Tenggara, Nur Alam pada 2009, dan pernyataan Gubernur Kalimantan Tengah, A Teras Narang pada 2010.

21 Pasal 10 dan Pasal 11 Undang-Undang Nomor 32 Tahun 2004 Tentang Pemerintahan Daerah.

22 Jimly Asshidiqie, Pokok-Pokok Hukum Tata Negara Indonesia, (Jakarta: Bhuana Ilmu Pupuler, 2007), hlm. 428.

23 Ibid. 
Salah satupenyebablain tidaktaatnya bupati/ walikota kepada gubernur adalah karena faktor pertentangan politis. ${ }^{24}$ Gubernur dan Bupati/ walikota merasa sama-sama sebagai kepala daerah otonom yang dipilih rakyat sehingga ego sektoral menjadi sulit dihindari, gubernur sama-sama menjadi pelaku pembangunan sebagaimana yang dilakukan oleh walikota/ bupati dalam upayanya memenuhi janji-janji semasa kampanye. ${ }^{25}$ Semakin kuat otonomi di tingkat provinsi maka akan melemahkan otonomi di kabupaten/kota dengan tetap tergantung kepada program-program gubernur, semakin banyak pelayanan publik yang harus dilaksanakan oleh perangkat provinsi, hal ini mengurangi hakikat otonomi untuk mendekatkan pelayanan publik kepada rakyat karena jarak antara pemerintah provinsi dengan rakyat terlalu jauh. Sementara itu pada tingkat kabupaten/kota yang lebih membutuhkan pembinaan dan fasilitasi, kurang terberdayakan kemampuan dan kemandiriannya. ${ }^{26}$ Lebih jauh Bagir Manan mengatakan bahwa otonomi di dua tingkat pemerintahan daerah menjadikan terjadinya overlapping territorial, overlapping wewenang, dan inefisiensi birokrasi. ${ }^{27}$

Di lain sisi terdapat banyak sekali dampak negatif yang muncul tatkala Bupati/Walikota bekerja tanpa pengawasan serta koordinasi yang ketat oleh gubernur selaku wakil Pemerintah Pusat di daerah, salah satu parameter nyata tidak adanya koordinasi dan keharmonisan di daerah adalah dengan banyaknya Peraturan Daerah (Perda) Kabupaten/Kota yang dibatalkan. Di era otonomi daerah, banyak Kabupaten/Kota mengeluarkan Perda bermasalah, yang dirasa mengganggu eksistensi dan kelangsungan Indonesia sebagai sebuah negara bangsa. Perdaperda tersebut bermasalah, baik dalam legalitas, substansi maupun inkonsistensi. Padahal Perda adalah landasan penyelenggaraan negara yang berdampak langsung kepada masyarakat di tingkat bawah. Banyaknya Perda bermasalah karena tidak adanya sinergi kebijakan antara pusat dengan daerah yang dalam hal ini di wakili Gubernur sebagai wakil Pemerintah Pusat dengan Kabupaten/Kota. Kabupaten/Kota cenderung bergerak sendiri dalam membuat dan mengesahkan Perda tanpa berkonsultasi atau meminta persetujuan Gubernur. ${ }^{28}$ Dalam kondisi seperti itu, maka dampaknya akan meluas sehingga rakyat juga yang dirugikan.

Gubernur sebagai pemimpin provinsi bertugas mengarahkan walikota dan bupati sebagai pemimpin kota/kabupaten untuk melakukan pembangunan dan pelayanan di daerahnya agar sinergis dan harmonis dengan pusat. Pelaksanaan otonomi daerah harus dapat menjamin hubungan yang serasi antara pemerintah pusat dengan daerah atas dasar keutuhan negara kesatuan, dan juga harus menjamin perkembangan dan pembangunan daerah. ${ }^{29}$ Untuk melaksanakan tugas itu maka gubernur haruslah memiliki kewenangan yang

24 Dalam banyak kasus, Gubernur dan walikota/bupati yang terlibat konflik berasal dari partai yang berbeda.

25 Inna Junaenah, "Implikasi Pemilihan Gubernur Secara Langsung Terhadap Kedudukan Gubernur Sebagai Wakil Pemerintah Pusat" Jurnal Konstitusi (Vol II Juni 2010): 62.

26 Ibid.

27 Inna Junaenah, "Menemukan Kedudukan Gubernur Sebagai Wakil Pemerintah Di Masa Transisi Otonomi", (makalah disampaikan dalam simposium nasional di Universitas Padjadjaran Tahun 2012).

28 Kisno Hadi, Op.Cit.

29 Ateng Syafrudin, Pasang Surut Otonomi Daerah, (Bandung: Binacipta, 1985), hlm. 35. 


\section{$\mathrm{R}_{\text {juknaL }}^{\text {juTSVINDING }}$}

Media Pembinaan Hukum Nasional

Volume 1 Nomor 3, Desember 2012

kuat dan tak dapat dinafikkan oleh bupati maupun walikota, namun nyatanya hingga saat ini masih banyak walikota/bupati yang mengabaikan eksistensi gubernur sebagai wakil pemerintah pusat. ${ }^{30}$ Perlu ditegaskan sekali lagi bahwa peran dan fungsi gubernur sebagai wakil pemerintah pusat sebagai salah satu instrumen sentralisasi ${ }^{31}$ yang penting untuk melaksanakan tugas konstitusional menghantarkan daerahdaerah kepada pada masa transisi otonomi. ${ }^{32}$

Kewenangan yang dimiliki oleh gubernur seperti diatur dalam Undang-Undang Pemerintahan Daerah dan Peraturan Pelaksana terkait menunjukkan bahwa peran gubernur sebagai wakil pemerintah pusat-lah yang perlu diperkuat agar pemerintahan dan penyelenggaraan negara dapat berjalan dengan baik dan konstitusional. Secara redaksional pun, kata-kata yang tercantum dalam UndangUndang Pemerintahan Daerah seperti pembinaan, koordinasi, pengawasan ataupun supervisi, fasilitasi, monitoring, evaluasi, secara esensi menunjukkan peran gubernur sebagai wakil pemerintah pusat. ${ }^{33}$ Arah optimalisasi yang dapat dikembangkan darifungsigubernuradalah dengan berfokus kepada pelaksanaan fungsi pembinaan, pengawasan, dan koordinasi. ${ }^{34}$ Sehingga di masa yang akan datang perlu dilakukan kebijakan terkait pembatasan otonomi provinsi atau bahkan penghapusan. Bagir Manan mengatakan bahwa semakin optimal tugas gubernur sebagai wakil pemerintah maka otonomi di provinsi akan semakin terbatas. ${ }^{35}$ Dalam konteks yang sama, Ateng Syafrudin mengatakan bahwa semakin luas otonomi daerah dalam rangka desentralisasi, maka sedikit fungsi-fungsi dekonsentrasi. ${ }^{36}$ Sehingga untuk mengoptimalkan fungsi gubernur dalam kaitannya sebagai wakil pemerintah yang melaksanakan dekonsentrasi maka tidak perlu diadakan pemilihan langsung untuk memilih gubernur di tingkat provinsi, karena pemilihan langsung lebih tepat jika dilaksanakan di daerah otonom yang melakukan desentralisasi secara penuh, dalam hal ini kabupaten/kota.

\section{Pemilihan Kepala Daerah}

Pemilihan kepala daerah secara langsung dapat dikatakan sebagai salah satu bentuk nyata pelaksanaan otonomi daerah, dimana rakyat dapat langsung memilih para pemimpin yang dikehendaki secara langsung. Mekanisme kampanyedan proseslain akan mampumembuat para calon pemimpin daerah dikenal lebih baik oleh rakyatnya, hal ini sangatlah penting karena salah satu tujuan dan desentralisasi

30 Suryo Sakti Hadiwijoyo, Gubernur, (Jakarta: Grha Ilmu, 2011), hlm. viii.

31 Dianutnya desentralisasi dalam organisasi negara tidak berarti ditinggalkannya asas sentralisasi, karena asas tersebut tidak bersifat dikotomis, melainkan kontinum. Pada prinsipnya, tidaklah mungkin diselenggarakan desentralisasi tanpa sentralisasi, sebab desentralisasi tanpa sentralisasi, akan menghadirkan disintegrasi. Desentralisasi bukanlah alternatif dari sentralisasi, dalam satu negara tidak mungkin dianut hanya asas sentralisasi saja untuk semua urusan, dan demikian pula sebaliknya.

32 Hal senada diungkapkan Inna Junaenah dalam makalah berjudul "Menemukan Kedudukan Gubernur Sebagai Wakil Pemerintah Di Masa Transisi Otonomi", dibawakan dalam simposium nasional di Universitas Padjadjaran Tahun 2012.

33 Menurut Peraturan Pemerintah Nomor 38 Tahun 2007 tentang Pembagian Urusan Pemerintahan Antara Pemerintah, Pemerintahan Daerah Provinsi, dan Pemerintahan Daerah Kabupaten/Kota.

34 Inna Junaenah, Op.Cit.

35 Ibid.

36 Inna Junaenah, "Implikasi Implikasi Pemilihan Gubernur Secara Langsung Terhadap Kedudukan Gubernur Sebagai Wakil Pemerintah Pusat”, Jurnal Konstitusi (Vol II Juni 2010): 62. 
dan otonomi daerah. Diberikannya otonomi kepada daerah melalui proses desentralisasi, tidak terlepas dari tujuan negara, Dalam hal ini, otonomi memiliki sejumlah fungsi terkait dengan tujuan pemberian otonomi. Bagir Manan mengidentifikasi 5 fungsi dari otonomi, salah satunya adalah fungsi pelayanan publik ${ }^{37}$, yaitu agar lebih dekat dengan rakyat yang wajib dilayani. ${ }^{38}$ Dengan adanya desentralisasi diharapkan pelayanan kepada masyarakat akan berjalan dengan lebih baik dan optimal dengan peningkatan efesiensi dan efektifitas. ${ }^{39}$ Dalam konteks ini maka pemilihan kepala daerah secara langsung dapat dianggap sebagai sesuatu yang ideal.

Dari paparan diatas maka perlu dipahami pula mengenai kepala daerah dan daerah-daerah mana yang tepat dalam pengimplementasian pemilihan kepala daerah secara langsung. Pelayanan publik secara nyata hanya terjadi di daerah yang memiliki teritorial yaitu kabupaten/kota, sedangkan provinsi adalah penyebutan secara administrasi terkait wilayah kerja gubernur, ${ }^{40}$ yang terdiri atas beberapa kabupaten/kota sekaligus merupakan daerah yang dipimpin oleh seorang gubernur sebagai perwakilan pemerintah pusat di daerah. Meskipun pada umumnya sama-sama disebut daerah, namun perlu dibedakan antara kota/ kabupaten sebagai daerah otonom dan provinsi sebagai wilayah administratif:

a. Kabupaten/kota merupakan daerah otonom yang pemerintahannya berada dalam lingkup pemerintahan daerah otonom yang memiliki ciri-ciri kemandirian untuk menjalankan urusan rumah tangganya termasuk memilih sendiri para pejabat-pejabat, termasuk mengangkat dan memberhentikannya ${ }^{41}$ maka memilih langsung kepala daerahnya dalam hal ini bupati dan walikota tentunya menjadi langkah yang tepat, karena merekalah yang akan memimpin daerahnya dan berhubungan secara langsung dengan masyarakat daerahnya, janji-janji dan komitmen kepala daerah semasa kampanye pun akan menjadi tanggung jawab secara langsung antara pemimpin dan rakyatnya.

b. Provinsi merupakan wilayah administratif, karena pelaksanaan tugas-tugas dan kewenangan gubernur serta lembaga provinsi dalam menjalankan kewenangan yang dilimpahkan oleh pemerintah pusat. Pemerintahan wilayah administratif adalah satuan pemerintah daerah di bawah pemerintahan pusat yang semata-mata hanya menyelenggarakan pemerintahan pusat di wilayah negara. Adapun ciri-ciri dari pemerintahan wilayah administratif adalah:42

1) Satuan pemerintahan semacam ini pada hakikatnya adalah perpanjangan tangan dari pemerintah pusat;

2) Penyelenggaraan urusan pemerintahn hanyalah bersifat administrasi semata;

3) Pelaksananya adalah pejabat-pejabat pemerintah pusat yang ditempatkan di daerah;

Empat fungsi lainnya adalah: fungsi pengelolaan pemerintahan, fungsi politik, fungsi polisionil, dan fungsi keragaman.

38 Bagir Manan, "Tugas Sosial Pemerintahan Daerah", opini, Pikiran Rakyat, 28 November 2008.

39 Badrul Munir, Perencanaan Daerah Dalam PerspektifOtoda, (Mataram: Bappeda, 2002, hlm. 28.

40 Penjelasan Undang-Undang Nomor 32 Tentang Pemerintahan Daerah.

41 Suryo Sakti Hadiwijoyo, Gubernur, (Jakarta: Grha Ilmu, 2011), hlm. 45.

$42 \quad$ Ibid., hlm. 44. 


\section{$\mathrm{R}_{\text {juknaL }}^{\text {juTSVINDING }}$}

Media Pembinaan Hukum Nasional

4) Hubungan antara pemerintahan wilayah administrasi dan pemerintahan pusat adalah hubungan antara atasan dan bawahan dalam rangka menjalankan perintah;

5) Seluruh penyelenggaraan pemerintahannya dibiayai dan menggunakan sarana dan prasarana dari pusat. ${ }^{43}$

Dari paparan diatas maka gubernur sebagai pejabat wilayah administrasi mempertanggungjawabkan pelaksanaan tugasnya ke pusat dan bukan kepada rakyat di daerah tersebut. Rakyat pun tidak dapat meminta pertanggungjawaban perihal kebijakan yang telah digariskan pusat, Pejabat dekonsentrasi hanya bertanggungjawab dari aspek pelaksanaan dari kebijakan tersebut. ${ }^{44}$ Maka sesungguhnya tidak perlu gubernur dipilih secara langsung oleh masyarakat, karena memang tidak ada kewenangan yang melahirkan suatu pertanggungjawaban antara gubernur dengan rakyat, pemilihan gubernur secara langsung oleh rakyat tidak relevan karena interaksi yang terjalin antara rakyat dan gubernur tidak bersifat langsung. Halini berbeda dengan kedudukan bupati/walikota sebagai kepala pemerintah kabupaten/kota sebagai unit langsung yang memberikan pelayanan langsung kepada masyarakat sehingga berakibat sebagai interaksi yang berbasis kepercayaan. ${ }^{45}$ Di daerah otonom seperti kabupaten dan kota, rakyat dapat benar-benar memilih sendiri seorang kepala daerah sesuai dengan aspirasinya, hal ini dapat dikatakan sejalan dengan pendapat Bagir Manan bahwa daerah yang otonom dan mandiri layak diberi tempat untuk mengurus rumah tangganya sendiri sehingga tidak ada alasan bagi daerah untuk memisahkan diri dari Republik Indonesia. ${ }^{46}$

Undang-Undang Pemerintahan Daerah menyebutkan bahwa sebagai wakil pemerintah pusat di daerah, gubernur memiliki fungsi koordinasi, pembinaan, dan pengawasan. ${ }^{47}$

Dalam sistem otonomi daerah Indonesia, terdapat dua pola hubungan yaitu pola hubungan antara pusat dan provinsi dan pola hubungan antara provinsi dan kabupaten/kota.

Dengan demikian, pusat hanya berhubungan secara langsung dengan provinsi, sedangkan hubungannya dengan kabupaten kota tidak secara langsung, melainkan harus melalui provinsi. Hal tersebut memperlihatkan bahwa gubernur bertindak sebagai perantara dan "jembatan" antara pusat dan daerah, gubernur menjadi pengawas pelaksanaan programprogram pembangunan dan pelayanan publik di daerah (kabupaten/kota), karena dalam penyelenggaraan pemerintahan daerah, pengawasan merupakan unsur yang tidak terpisahkan dari kebebasan berotonomi. Antara kebebasan dan kemandirian berotonomi di satu pihak dan pengawasan di pihak lain, merupakan dua sisi dari satu lembar mata uang

43 Pasal 38 ayat (2) Undang-Undang Nomor 32 Tahun 2004 tentang Pemerintahan Daerah mengamanatkan pendanaan tugas dan wewenang Gubernur sebagai wakil pemerintah di wilayah provinsi dibebankan kepada Anggaran Pendapatan dan Belanja Negara; Ciri bahwa gubernur merupakan bagian dari pemerintahan wilayah administrasi semakin terlihat dengan diterbitkannya Peraturan Pemerintah Nomor 19 Tahun 2010 tentang Tata Cara Pelaksanaan Tugas dan Wewenang serta Kedudukan Keuangan Gubernur sebagai Wakil Pemerintah di Wilayah Provinsi yang kemudian direvisi dengan terbitnya Peraturan Pemerintah Nomor 23 Tahun 2011.

44 Suryo Sakti Hadiwijoyo, Op.Cit., hlm. 66.

45 Hal senada diutarakan oleh menteri dalam negeri seperti dikutip dari http://www.radarsulteng.co.id/index. php/berita/detail/Rubrik/43/6090, (diakses 25 Februari 2013 pukul 12:30).

46 Inna Junaenah, Op.Cit, hlm. 58.

47 Pasal 38 Undang-Undang Nomor 32 Tahun 2004 Tentang Pemerintahan Daerah. 
dalam negara kesatuan dengan sistem otonomi (desentralisasi). ${ }^{48}$

Dengan sistem yang ada sekarang, dimana provinsi menjadi daerah otonom sekaligus wilayah administrasi menimbulkan konsekuensi terhadap kedudukan gubernur, selain sebagai kepala daerah, gubernur juga berkedudukan sebagai wakil pemerintah pusat di daerah yang berkewajiban menjalankan kewenangan pemerintahan yang dilimpahkan kepadanya. Namun tidak dapat dinafikkan, bahwa dwi status yang disandang gubernur cenderung membuka peluang terjadinya tumpang tindih perhatian antara kedua peran. Konflik ini akan terjadi ketika gubernur menghadapi masalah untuk menunda kebijakan pemerintah pusat yang memiliki kemungkinan bertentangan dengan aspirasi masyarakat daerah. ${ }^{49}$ Dan kegamangan serta tarik ulur antara dua status itu akan semakin kuat jika gubernur dipilih langsung oleh masyarakat.

\section{Menuju Pemilihan Gubernur Tidak Langsung}

Paparan sebelumnya menunjukkan bahwa untuk memperkuat kewenangan kedudukan Gubernur sangat sangat penting dalam pemerintahan, maka yang perlu/diperkuat adalah peranan dan wewenangnya sebagai wakil pemerintah pusat. Hakikat bahwa gubernur adalah perpanjangan tangan dari pemerintah pusat di daerah justru mempermudah itu, asas dekonsentrasi serta mandat langsung dari Presiden menjadikan gubernur dapat berperan secara konsisten dengan kewenangannya yang memang terbatas namun strategis sebagai pembina, pengawas dan koordinator daerah kabupaten/kota, juga karena hubungan antara gubernur dengan rakyat adalah berupa hubungan tidak langsung, sehingga seharusnya tidak ada yang dijanjikan oleh gubernur kepada masyarakat seperti yang terjadi dalam kampanye-kampanye, gubernur tidak bertanggung jawab kepada rakyat melainkan kepada pemerintah pusat. Pemilihan gubernur secara langsung memiliki berimplikasi kepada gubernur yang lebih menonjolkan peranannya sebagai seorang kepala daerah daripada sebagai wakil pemerintah pusat. Hal-hal tersebut dapat membuat kita kembali memperdebatkan mengenai mekanisme pemilihan gubernur secara langsung yang dilakukan saat ini.

Pasal 18 UUD 1945 menghendaki bahwa pemilihan kepala daerah dilakukan secara demokratis, Pasal 18 ayat (4) UUD 1945 menyatakan: "Gubernur, Bupati, dan Walikota masing-masing sebagai Kepala Pemerintah Daerah Provinsi, Kabupaten dan Kota dipilih secara demokratis", dan cara demokratis itu bukanlah pemilihan secara langsung oleh rakyat semata. Cara pemilihan langsung seperti yang diimplementasikan seperti saat ini layak diappresiasi dan dipertahankan, namun lebih tepat jika cara seperti itu dilakukan di tingkatan kabupaten/kota bukan provinsi, karena berkaitan dengan hubungan dan interaksi secara langsung antara rakyat dan kepala daerah seperti telah diuraikan sebelumnya, juga karena otonomi yang sesungguhnya dalam konteks desentralisasi terdapat di kabupaten/

48 Bagir manan, Menyongsong Fajar Otonomi Daerah, (Yogyakarta: PSH UII, 2005), hlm. 154.

49 Inna Junaenah, "Menemukan Kedudukan Gubernur Sebagai Wakil Pemerintah Di Masa Transisi Otonomi", (makalah disampaikan dalam simposium nasional "Satu Dasawarsa Perubahan Undang-Undang Dasar 1945: Indonesia Menuju Negara Konstitusional?", diselenggarakan bagian Hukum Tata Negara Universitas Padjadjaran 31 Oktober-1 November 2012). 


\section{$\mathrm{R}_{\text {juknaL }}^{\text {juTSVINDING }}$}

kota. Bagir manan menekankan pentingnya pemilihan secara langsung berkaitan dengan otonomi daerah. ${ }^{50}$

Seperti dijelaskan diatas bahwa esensi dari "dipilih secara demokratis" yang dimaksud oleh Pasal 18 UUD 1945 tidaklah dipersempit dalam pengertian dipilih secara langsung oleh masyarakat. Kemudian muncullah beberapa alternatif sebagai solusi, yaitu: ${ }^{51}$

1. Kedudukan dan kewenangan gubernur menjadi setingkat menteri;

2. Gubernur diangkat langsung oleh Presiden;

3. Gubernur dipilih oleh DPRD.

Daribeberapa alternatif tersebut, tampaknya pilihan ketiga bahwa gubernur dipilih oleh DPRD lah yang memenuhi unsur "dipilih secara demokratis".52 Tentunya kritik akan kembali muncul dengan alternatif ini, seakan-akan menjadi langkah mundur, namun kembali kita kembali kepada hakikat bahwa sesungguhnya kewenangan gubernur memang sangat terbatas, juga hanya sebagai perpanjangan tangan dari pemerintah pusat.

Pemilihan secara langsung maupun tidak langsung tetap menimbulkan sisi negatif, seperti money politics, jual beli suara dan sebagainya namun dalam konteks pemilihan oleh DPRD pengawasannya lebih mudah karena jumlah anggota DPRD lebih sedikit, juga dapat dihindari jatuhnya korban jiwa akibat bentrokan antara para pendukung calon gubernur. Dalam pemilihan secara langsung maka gelanggang kompetitif dari dalam parlemen pindah ke luar parlemen, sehingga perlu pengendalian ekstra ketat agar tidak menimbulkan konflik keras di tengah-tengah masyarakat (konflik horisontal) yang dapat mengganggu keamanan serta menimbulkan korban jiwa dan harta benda. ${ }^{53}$

Dari pemaparan sebelumnya diuraikan bahwa gubernur bertugas sebagai koordinator, pengawas, dan pembina di daerah. Untuk melaksanakan tugas-tugas tersebut, terlebih dengan kedudukannya sebagai wakil pemerintah pusat, tentunya dibutuhkan sosok yang memiliki pengalaman, kualitas dan kemampuan teruji. Menurut penelitian Badan Pembinaan Hukum Nasional, Kepala Daerah yang dipilih oleh DPRD memiliki kualitas lebih baik karena telah mengenal birokrasi, sistem pemerintahan daerah dan daerahnya secara baik, ${ }^{54}$ sedangkan yang dipilih secara langsung cenderung menghasilkan sosok yang kurang berkualitas, karena pemilihan secara langsung membuka peluang bagi seluruh lapisan masyarakat yang awam sekalipun dan para pendatang baru, meskipun secara akuntabilitas publik sangat teruji, namun justru bukan itulah yang diperlukan untuk menjalankan tugas gubernur dengan kewenangan yang terbatas itu, terlebih gubernur memang tidak bertanggung jawab kepada publik melainkan pemerintah pusat, dan Presiden sebagai pemberi mandat.

$50 \quad$ Ibid.

51 Inna Junaenah, Implikasi Op.Cit., hlm. 65.

52 Terdapat dua cara pengisian jabatan yang dinilai dilakukan secara demokratis (Mourice Deverger) yakni: Pertama, demokrasi secara langsung merupakan cara pengisisan jabatan dengan rakyat secara langsung memilih seseorang untuk meduduki jabatan tertentu dalam pemerintahan; Kedua, demokrasi perwakilan cara pengisian jabatan dengan rakyat memilih seseorang atau partai politik untuk memilih seseorang menduduki jabatan tertentu guna menyelenggarakan tugas negara.

53 Puslitbang BPHN, Pemilihan Kepala Daerah (Jakarta: BPHN, 2011), hlm. 36.

$54 \quad$ Ibid, hlm 34-35 


\section{E. Penutup}

Gubernur memiliki dua status, sebagai kepala daerah dan juga sebagai wakil pemerintah pusat didaerah. Dalam rangka penyelenggaraan negara dan agar pemerintahan di daerah berlangsung dengan baik maka optimalisasi peran gubernur yang diperkuat adalah sebagai perwakilan pemerintah pusat di daerah dengan pelaksanaan fungsi pembinaan, koordinasi dan pengawasan terhadap kabupaten/kota. Namun mekanisme pemilihan gubernur secara langsung seperti saat ini ternyata justru membuat gubernur lebih dominan dan berperan sebagai seorang kepala daerah daripada wakil pemerintah pusat. Alternatif untuk menegaskan dan memperkuat kedudukan gubernur sebagai wakil pemerintah pusat di daerah dan melaksanakan pelimpahan wewenang dari pusat dalam rangka asas dekonsentrasi adalah melalui pemilihan tidak langsung, alasan lainnya adalah karena pada hakikatnya gubernur tidak bertanggung jawab kepada rakyat namun kepada pemberi mandat. Hingga saat ini mekanisme pemilihan gubernur secara tidak langsung yang paling memungkinkan dan tidak bertentangan dengan Undang-Undang Dasar adalah pemilihan oleh DPRD provinsi karena tetap memenuhi unsur pemilihan secara demokratis.

\section{DAFTAR PUSTAKA}

\section{Buku}

Asshidiqie, Jimly, Pokok-Pokok Hukum Tata Negara Indonesia, (Jakarta: Bhuana Ilmu Pupuler, 2007).

BPHN, Pemilihan Kepala Daerah (Jakarta: BPHN, 2011).

Hadiwijoyo, Suryo Sakti, Gubernur, (Jakarta: Grha Ilmu, 2011).

Manan, Bagir, Menyongsong Fajar Otonomi Daerah, (Yogyakarta: PSH UII, 2005).
Manan, Bagir dan Kuntana Magnar, Beberapa Masalah Hukum Tata Negara Indonesia,

(Bandung: Alumni, 1997).

Munir, Badrul, Perencanaan Daerah Dalam Perspektif Otoda, (Mataram: BAPPEDA, 2002).

Nurcholis, Hanif, Teori dan Praktek Pemerintahan dan Otonomi Daerah, (Jakarta: Grasindo, 2007).

Syafrudin, Ateng, Pasang Surut Otonomi Daerah, (Bandung: Binacipta, 1985).

Soekanto, Soerjono dan Sri Mamudji, Penelitian Hukum Normatif: Suatu Tinjauan Singkat, (Jakarta: Raja Grafindo Persada, 2001).

\section{Makalah/Artikel/Prosiding/Hasil Penelitian}

Bagir Manan, "Penelitian Terapan di Bidang Hukum", makalah, disampaikan pada Lokakarya Peranan Naskah Akademis Dalam Penyusunan Peraturan Perundang-undangan, BPHN, Jakarta, $9-11$ November 1993,

Bagir Manan, "Tugas Sosial Pemerintahan Daerah:, opini, Pikiran Rakyat, 28 November 2008.

Kisno Hadi," Satu Dasawarsa Relasi Politik Lokal Dan Nasional Dalam Konteks Otonomi Daerah" POLITIKA vol 1 No 2 (2010) : 5

Inna Junaenah, Implikasi Pemilihan Gubernur Secara Langsung TerhadapKedudukan Gubernur Sebagai Wakil Pemerintah Pusat, Jurnal Konstitusi Vol II Juni 2010,

Inna Junaenah, "Menemukan Kedudukan Gubernur Sebagai Wakil Pemerintah Di Masa Transisi Otonomi", dibawakan dalam simposium nasional di Universitas Padjadjaran Tahun 2012.

\section{Internet}

http://www.radarsulteng.co.id/index.php/berita/ detail/Rubrik/43/6090

\section{Peraturan}

Undang-Undang Dasar 1945

Undang-Undang Nomor 32 Tahun 2004 Tentang Pemerintahan Daerah

Peraturan Pemerintah Nomor 7 Tahun 2008

Peraturan Pemerintah Nomor 19 Tahun 2010

Peraturan Pemerintah Nomor 23 Tahun 2011 